\title{
Meningkatkan Prestasi Belajar IPS Materi Sistem Administrasi Wilayah Indonesia dengan Model Pembelajaran Talking Stick bagi Siswa Kelas VI SDN 3 Craken Trenggalek
}

\author{
Rukani \\ SDN 3 Craken Trenggalek, Indonesia \\ Email: kaniarum@gmail.com
}

\begin{abstract}
Abstrak: Penelitian ini bertujuan untuk meningkatkan prestasi belajar siswa kelas VI SDN 3 Craken dengan menggunakan model pembelajaran Talking Stick. Penelitian ini merupakan penelitian tindakan kelas dengan 2 siklus. Tahapan pelaksanaan penelitian ini dengan tahap perencanaan, pelaksanaan, pengamatan dan refleksi. Hasil penelitian menunjukkan bahwa terjadi peningkatan signifikan rata - rata prestasi belajar dari $73 \%$ pada siklus 1 ke $91 \%$ pada siklus 2 ( meningkat sebesar $18 \%$ ). Dari hasil penelitian tersebut dapat disimpulkan bahwa prestasi belajar siswa meningkat secara signifikan dengan menggunakan model pembelajaran Talking stick.
\end{abstract}

\begin{tabular}{l}
\hline Tersedia Online di \\
\hline http://journal.unublitar.ac.id/pendidika \\
\hline n/index.php/Riset_Konseptual \\
\hline Sejarah Artikel \\
\hline Diterima pada : 19-06-2020 \\
Disetuji pada : 30-07-2020 \\
Dipublikasikan pada : 31-07-2020 \\
\hline Kata Kunci: \\
\hline Prestasi Belajar, IPS, Talking Stick \\
DOI: \\
http://doi.org/10.28926/riset_konseptual.v4i3. \\
258
\end{tabular}

\section{PENDAHULUAN}

Sering kita dengar istilah prestasi belajar dalam kehidupan sehari-hari, terutama dalam kancah dunia pendidikan. Masalah prestasi belajar biasanya dikaitkan dengan hasil yang dapat dicapai oleh siswa di sekolah. Prestasi belajar merupakan salah satu hal yang dijadikan sebagai simbol kebanggaan dari suatu lembaga pendidikan.

Sekolah yang dapat mencetak siswa yang berprestasi tinggi dalam setiap mata pelajaran yang disampaikan biasanya menjadi sekolah idola. Sebaliknya apabila prestasi belajar siswanya rendah biasanya juga menjadi sekolah yang "tersingkir" dari persaingan, terutama dalam merekrut siswa baru.

Begitu pentingnya masalah prestasi belajar bagi kelangsungan kehidupan dan kelancaran kegiatan belajar mengajar bagi lembaga pendidikan. Sehingga masalah ini harus benar-benar diperhatikan oleh seluruh komponen yang berkecimpung dalam dunia pendidikan. Agar dalam memahami istilah prestasi belajar tidak mengalami penyimpangan, maka berikut akan disampaikan kutipannya. Moeliono (2001) mengungkapkan bahwa prestasi belajar adalah penguasaan pengetahuan atau ketrampilan yang dikembangkan dari suatu mata pelajaran. Penguasaan ini biasanya ditampilkan dengan berupa nilai atau angka

Dari kutipan yang disampaikan tersebut semakin memperkuat dan memperdalam keyakinan kita, bahwa prestasi belajar adalah hasil yang dapat dicapai oleh siswa setelah siswa melakukan kegiatan belajar. Sebagaimana kita ketahui, pada setiap kurun waktu tertentu, siswa melakukan evaluasi, dan hasil dari evaluasi tersebut biasanya berwujud angka (nilai). Inilah yang dimaksud dengan prestasi belajar. Sedangkan apabila ditinjau dari asal katanya, prestasi belajar merupakan gabungan dari dua kata, yaitu prestasi dan belajar. Dalam Kamus Umum Bahasa Indonesia disebutkan bahwa yang dimaksud dengan prestasi adalah: "Hasil yang telah dicapai dari apa yang dilakukan, dikerjakan, dan lain-lain" (Moeliono, 2001). 
Belajar mempunyai pengertian yang sangat beragam. Aktifitas belajar merupakan aktifitas yang sangat diperhatikan dalam dunia pendidikan. Untuk itu perlu kiranya kita ambil beberapa pengertian sebagai dasar pembahasannya. Pasaribu (2003) berpendapat bahwa belajar merupakan suatu proses perubahan kegiatan terhadap suatu keadaan atau lingkungan. Dalam melaksanakan kegiatan belajar, tidak jarang akan mengalami gangguan dan kesulitan belajar. Kesulitan yang tidak segera dapat diatasi, dapat menimbulkan kesulitan-kesulitan lainnya. Untuk itu apabila muncul permasalahan yang berkaitan dengan kesulitan belajar hendaknya dapat segera diatasi.

Beberapa faktor yang berkaitan dengan kesulitan belajar antara lain faktor intern dan faktor ekstern. Faktor intern ini merupakan faktor yang terdapat pada diri siswa dan ada dengan sendirinya. Faktor intern sangat mempengaruhi seberapa besar kesulitan belajar yang dihadapi. Faktor ini masih terbagi lagi menjadi penyebab yang bersifat fisik dan penyebab yang bersifat rohani. Faktor intern ini antara lain: faktor fisik dan faktor rohani. Sedangkan faktor ekstern antara lain adalah faktor lingkungan keluarga, faktor lingkungan masyarakat maupun faktor lingkungan sekolah. Salah satu mata pelajaran yang dipelajari dalam lingkungan sekolah adalah mata pelajarsn IPS

IImu Pengetahuan Sosial (IPS) adalah suatu bidang yang mengkaji tentang gejala-gejala sosial dan masalah yang terjadi di masyarakat (Astuti, 2006). Mata pelajaran IImu Pengetahuan Sosial yang diberikan kepada siswa mempunyai fungsi untuk mengembangkan pengetahuan dan ketrampilan baik sikap maupun kemampuan dasar untuk memahami kehidupan sosial dikehidupan sehari - hari. Sedangkan belajar sejarah dapat menumbuhkembangkan rasa kebangsaan (Dinas Pendidikan dan Kebudayaan, 2002). Di samping fungsinya, maka perlu kiranya dikaji mengenai tujuan dari mata pelajaran IImu Pengetahuan Sosial. Tujuan dari mata pelajaran ini dapat dilihat dari dua sudut pandang, yaitu sebagai pengajaran Pengetahuan Sosial dan sebagai pengajaran sejarah. Mata pelajaran Ilmu Pengetahuan Sosial di Sekolah Dasar bertujuan agar siswa mampu mengembangkan pengetahuan dan ketrampilan dasar yang berguna bagi dirinya dalam kehidupan sehari-hari.

Pembelajaran pra siklus materi yang dipelajari adalah "Profil Indonesia." Pada tahap pra siklus ditetapkan KKM individual sebesar 70 dan KKM kelas sebesar $80 \%$. Ketuntasan kelas yang dapat dicapai sebesar $64 \%$, sehingga tingkat kegagalan masih $36 \%$. Sesuai dengan tingkat ketuntasan klasikal yang dicapai, maka perlu dilakukan penelitian sehingga tingkat ketuntasan belajar dan prestasi belajar siswa dapat meningkat.

Pembelajaran pada tahap pra siklus mempergunakan metode ceramah dan Tanya jawab dengan siswa. Tentunya metode ini merupakan metode mengajar yang menjadi favorit para guru karena dianggap sebagai metode mengajar yang paling mudah untuk dilaksanakan terutama bagi anak usia Sekolah Dasar. Sebenarnya penggunaan metode ceramah dan Tanya jawab tidak selalu salah. Tetapi apabila guru menggunakannya secara monoton dan terus menerus, tentunya siswa akan menjadi bosan. Faktor kebosanan inilah yang kemudian memicu turunnya prestasi belajar siswa.

Berkaitan dengan hal tersebut di atas, maka guru perlu memikirkan model pembelajaran yang menarik bagi anak. Apabila anak merasa tertarik, maka dia akan termotivasi untuk belajar. Sementara itu, motivasi belajar dapat meningkatkan aktifitas belajar siswa yang pada akhirnya akan bermuara pada hasil belajar yang maksimal.

Menurut Kagan (1994), belajar kooperatif adalah suatu istilah yang digunakan dalam prosedur pembelajaran interaktif, dimana siswa belajar bersama-sama dalam kelompok kecil untuk memecahkan berbagai masalah. Menurut David dan Roger (2002), pembelajaran kooperatif merupakan aktifitas pembelajaran kelompok yang diorganisir oleh satu prinsip bahwa pembelajaran harus didasarkan pada perubahan informasi secara sosial diantara kelompok-kelompok belajar yang di dalamnya setiap pembelajar bertanggung jawab atas pembelajarannya sendiri dan didorong untuk meningkatkan pembelajaran anggota-anggota yang lain. Menurut Anita Lie (2002), 
pembelajaran kooperatif merupakan sistem pembelajaran yang memberikan kesempatan pada siswa untuk bekerjasama sesamanya pada saat mengerjakan tugas terstruktur. Sedangkan menurut Eggen dan Kauchak (1993) pembelajaran kooperatif merupakan sebuah kelompok strategi pengajaran yang melibatkan siswa bekerja secara kolaborasi untuk mencapai tujuan bersama.

Model pembelajaran talking stick merupakan salah satu dari model pembelajaran kooperatif, guru memberikan siswa kesempatan untuk bekerja sendiri serta bekerja sama dengan orang lain dengan cara mengoptimalisasikan partisipasi siswa (Lie, 2002). Menurut Widodo (2009) mengemukakan bahwa talking stick merupakan suatu model pembelajaran yang menggunakan sebuah tongkat sebagai alat penunjuk giliran. Siswa yang mendapat tongkat akan diberi pertanyaan dan harus menjawabnya. Kemudian secara estafet tongkat tersebut berpindah ke tangan siswa lainnya secara bergiliran.

Berdasarkan uraian tersebut, pembelajaran talking stick merupakan salah satu dari model pembelajaran kooperatif yang menggunakan sebuah tongkat sebagai alat penunjuk giliran dengan memberikan siswa kesempatan untuk bekerja sendiri serta bekerja sama dengan orang lain sehingga mengoptimalisasikan partisipasi siswa. Hasil refleksi yang dilakukan di SDN 3 Craken Kecamatan Munjungan Kabupaten Trenggalek" dapat disampaikan dari tahap pra siklus ini adalah: (1) Siswa kurang termotivasi dalam kegiatan belajar, (2) Guru mendominasi kegiatan pembelajaran, (3) Situasi belajar terlihat kaku dan mati, (4) Penggunaan media masih kurang maksimal.

Sehubungan dengan hasil refleksi di atas, maka peneliti berniat melaksanakan pembelajaran dengan model pembelajaran yang berbeda dari biasanya. Pembelajaran tersebut akan dilakukan dalam bentuk penelitian tindakan kelas. Dengan penelitian ini diharapkan mampu meningkatkan Prestasi Belajar IPS Materi Sistem Administrasi Wilayah Indonesia melalui Model Pembelajaran Talking Stick bagi Siswa Kelas VI Semester I di SDN 3 Craken Kecamatan Munjungan Kabupaten Trenggalek.

\section{METODE}

Penelitian ini merupakan penelitian tindakan kelas yang dilakukan dengan 2 siklus dan 4 tahapan, yaitu perencanaan, pelaksanaan tindakan, pengamatan, dan refleksi. Penelitian ini meneliti siswa kelas VI SDN 3 Craken Kecamatan Munjungan kabupaten Trenggalek Tahun pelajaran 2015/2016. yang bejumlah 11 siswa, yang terdiri dari 6 siswa perempuan dan 5 siswa laki-laki. Penelitian ini menggunakan lembar tes yang berwujud tes akhir. Masing-masing siklus menggunakan soal tes sebanyak 10 soal. Setiap soal dijawab benar memperoleh nilai 1, jika salah akan memperoleh nilai 0 . Soal tes yang dipergunakan adalah soal tes yang berwujud tes isian. Teknik pengumpulan data yang dipergunakan yaitu metode tes. Data yang diperoleh dari lokasi penelitian ada dua macam, yakni data keaktifan dan data prestasi belajar. Data tersebut dianalisis dengan cara mencari prosentase, sehingga dianalisis secara kuantitatif.

\section{Siklus 1}

\section{HASIL DAN PEMBAHASAN}

Siklus I dilaksanakan dengan menggunakan model pembelajaran Talking Stick. Tahap yang dilakukan ada 4 tahapan, yaitu perencanaan, pelaksanaan tindakan, pengamatan, dan refleksi

\section{a. Tahap Perencanaan}

Pada siklus I terjadi perubahan yang merupakan perbaikan dari pelaksanaan pra siklus, dimana pada siklus I ini perencanaan sudah disusun dengan menggunakan model pembelajaran Talking Stick. Perencanaan yang dilakukan meliputi: (1) menyiapkan silabus, (2) Mengembangkan skenario pembelajaran, (3) Menyiapkan sumber dan media pembelajara,(4) Menyusun LKS, (5) Menyusun instrument soal tes, (6) Menyusun format observasi pembelajaran. 


\section{b. Tahap Pelaksanaan}

Pada tahap ini guru melaksanakan pembelajaran dengan menerapkan model pembelajaran Talking Stick. Adapun tahapan yang dilakukan guru adalah: (1) Guru menjelaskan tujuan pembelajaran/KD (materi: perkembangan wilayah Indonesia), (2) menyiapkan sebuah tongkat, (3) menyampaikan materi pokok yang akan dipelajari, kemudian memberikan kesempatan kepada siswa untuk membaca dan mempelajari materi lebih lanjut, (4) mengambil tongkat dan memberikan kepada siswa, setelah itu guru memberikan pertanyaan dan siswa yang memegang tongkat tersebut harus menjawabnya, jika siswa sudah dapat menjawabnya maka tongkat kembali berputar sambil diiringi musik, (5) Demikian seterusnya sampai sebagian besar siswa mendapat bagian untuk menjawab setiap pertanyaan dari guru, (6) Guru memberikan kesimpulan.

\section{c. Tahap Pengamatan}

Pengamatan dilakukan oleh guru/peneliti pada saat kegiatan inti pembelajaran berlangsung. Siswa pasa siklus I menunjukkan tingkat keaktifan yang masih relatif rendah. Siswa belajar sambil banyak bergurau. Mungkin dengan model pembelajaran yang baru, siswa masih belum dapat focus dalam belajar

\section{d. Tahap Refleksi}

Hasil pengamatan dengan menggunakan lembar observasi dan hasil test akhir yang diberikan pada siklus I akan dijadikan sebagai bahan refleksi untuk siklus I. Adapun hasil test pada siklus I adalah sebagai berikut:

Tabel 1. Hasil Tes Siklus I

\begin{tabular}{|ccccccc|}
\hline Nilai & $\begin{array}{c}\text { Banyak } \\
\text { siswa }\end{array}$ & $\begin{array}{c}\text { Banyak } \\
\text { siswa } \\
(\%)\end{array}$ & $\begin{array}{c}\text { Banyak } \\
\text { siswa yang } \\
\text { tuntas KKM }\end{array}$ & $\begin{array}{c}\text { Banyak } \\
\text { siswa } \\
\text { yang } \\
\text { tuntas } \\
\text { KKM (\%) }\end{array}$ & $\begin{array}{c}\text { Banyak } \\
\text { siswa yang } \\
\text { tidak tuntas } \\
\text { KKM }\end{array}$ & $\begin{array}{c}\text { Banyak } \\
\text { siswa } \\
\text { yang tidak } \\
\text { tuntas } \\
\text { KKM (\%) }\end{array}$ \\
\hline $\mathbf{1 0 0}$ & 1 & 9 & 8 & 73 & 3 & 27 \\
\hline $\mathbf{9 0}$ & 2 & 18 & & & & \\
\hline $\mathbf{8 0}$ & 3 & 27 & & & & \\
\hline $\mathbf{7 0}$ & 2 & 18 & & & & \\
\hline $\mathbf{6 0}$ & 2 & 18 & & & & \\
\hline $\mathbf{5 0}$ & 1 & 9 & & & & \\
\hline Total & 11 & 100 & &
\end{tabular}

Pada siklus I ini nilai siswa dikelompokkan menjadi 6 kelompok (6 kelas interval). Siswa yang mendapat nilai 100 sebanyak 1 Siswa (9\%) Siswa yang mencapai nilai 90 sebanyak 2 Siswa (18\%). Siswa yang memperoleh nilai 80 sebanyak 3 Siswa 27\%). Siswa yang memperoleh nilai 70 sebanyak 2 Siswa (18\%), dan siswa yang memperoleh nilai 60 sebanyak 2 siswa (18\%), dan siswa yang memperoleh nilai 50 sebanyak 1 siswa (9\%).

Nilai rata-rata yang dapat dicapai siswa pada tahap siklus I ini adalah 75 . Sedangkan modus pada tahap pra siklus ini adalah 80 sebanyak 3 siswa atau sebesar $27 \%$.

Berdasarkan data di atas, dapat diketahui bahwa jumlah siswa ada 11 Siswa yang tuntas sebanyak 8 (73\%). Siswa yang tidak tuntas sebanyak 3 siswa (27\%). Karena ketuntasan kelas yang ditentukan minimal sebesar $80 \%$ tuntas, maka pembelajaran siklus I dinyatakan belum tuntas. Ada beberapa hal yang perlu dicatat dari pelaksanaan siklus I, sebagai berikut: (1) Siswa terlihat lebih aktif dari pada tahap pra siklus, (2) Nilai siswa juga sudah meningkat, (3) Pemberian tongkat sebaiknya dilakukan secara acak oleh siswa. Hal ini dapat dilakukan dengan cara siswa yang baru saja menerima tongkat (tugas) menunjuk temannya. Begitu seterusnya, (4) Masih perlu diadakan siklus II mengingat masih ada 28,6\% siswa yang belum tuntas. 


\section{Siklus 2}

Pada siklus II terjadi perubahan yang merupakan perbaikan dari pelaksanaan siklus I, dimana pada siklus II ini perencanaan sudah disusun sesuai dengan hasil refleksi dari siklus I.

\section{a. Tahap Perencanaan}

Model pembelajaran yang dipergunakan adalah Talking Stick sebagaimana dilaksanakan pada siklus I. Hal-hal yang dilakukan pada tahap perencanaan adalah: (1) Menyiapkan silabus, (2) Mengembangkan skenario pembelajaran, (3) Menyiapkan sumber dan media pembelajaran, (4) Menyusun LKS, (5) Menyusun instrument soal tes, (6) Menyusun format observasi pembelajaran

\section{b. Tahap Pelaksanaan}

Pada tahap ini guru melaksanakan pembeljaran dengan menerapkan model pembelajaran Talking Stick. Adapun tahapan yang dimaksud sama dengan pelaksanaan pada siklus I

\section{c. Tahap Pengamatan}

Pengamatan dilakukan oleh guru/peneliti pada saat kegiatan inti pembelajaran berlangsung. Hasil pengamatan menunjukkan bahwa siswa aktif sudah mendominasi. Hanya ada beberapa siswa yang kelihatan malu-malu. Guru juga telah fokus pada proses pembelajaran

\section{d. Tahap Refleksi}

Hasil pengamatan dengan menggunakan lembar observasi dan hasil test akhir yang diberikan pada siklus II akan dijadikan sebagai bahan refleksi untuk siklus II. Adapun hasil test pada siklus II adalah sebagai berikut:

\begin{tabular}{|ccccccc|}
\hline Nilai & $\begin{array}{c}\text { Banyak } \\
\text { siswa }\end{array}$ & $\begin{array}{c}\text { Banyak } \\
\text { siswa (\%) }\end{array}$ & $\begin{array}{c}\text { Tabel 2. Hasil Tes Siklus 2 } \\
\text { Biswa } \\
\text { yang } \\
\text { tuntas } \\
\text { KKM }\end{array}$ & $\begin{array}{c}\text { Banyak siswa } \\
\text { yang tuntas } \\
\text { KKM (\%) }\end{array}$ & $\begin{array}{c}\text { Banyak } \\
\text { siswa } \\
\text { tidak } \\
\text { tuntas } \\
\text { KKM }\end{array}$ & $\begin{array}{c}\text { Banyak } \\
\text { siswa } \\
\text { yang tidak } \\
\text { tuntas (\%) }\end{array}$ \\
\hline $\mathbf{1 0 0}$ & 3 & 27 & 10 & 91 & 1 & 9 \\
\hline $\mathbf{9 0}$ & 4 & 36 & & & & \\
\hline $\mathbf{8 0}$ & 2 & 18 & & & & \\
\hline $\mathbf{7 0}$ & 1 & 9 & & & & \\
\hline $\mathbf{6 0}$ & 1 & 9 & & & & \\
\hline $\mathbf{5 0}$ & 0 & 0 & & & & \\
\hline Total & 11 & 100 &
\end{tabular}

Pada siklus II ini nilai siswa dikelompokkan menjadi 6 kelompok (6 kelas interval). Siswa yang mencapai nilai 100 sebanyak 3 Siswa $(27 \%)$ Siswa yang mencapai nilai 90 sebanyak 4 Siswa (36\%). Siswa yang memperoleh nilai 80 sebanyak 2 Siswa 18\%). Siswa yang memperoleh nilai 70 sebanyak 1 Siswa (9\%), dan siswa yang memperoleh nilai 60 sebanyak 1 siswa (9\%), dan siswa yang memperoleh nilai 50 sebanyak 0 siswa $(0 \%)$.

Nilai rata-rata yang dapat dicapai siswa pada tahap siklus II ini adalah 86 . Sedangkan modus pada tahap pra siklus ini adalah 90 sebanyak 4 siswa atau sebesar $36 \%$. Berdasarkan data di atas, dapat diketahui bahwa jumlah siswa ada 11 Siswa yang tuntas sebanyak 10 (91\%). Siswa yang tidak tuntas sebanyak 1 siswa (9\%). Karena ketuntasan kelas yang ditentukan minimal sebesar $80 \%$ tuntas, maka pembelajaran siklus II dinyatakan sudah tuntas.

Ada beberapa hal yang perlu dicatat dari pelaksanaan siklus II yaitu: (1) Siswa terlihat sangat menikmati model pembelajaran Talking Stick, (2) Prestasi belajar siswa sudah memuaskan guru, (3) Pelaksanaan siklus pada penelitian ini sudah dianggap cukup.

Berdasarkan pelaksanaan pembelajaran dnegan menggunakan media talking stick terdapat perbandingan hasil belajar siswa yang signifikan. Perbadingan hasil belajar siswa pada siklus 1 dan siklus 2 dapat dilihat pada tabel berikut 
Tabel 3. Perbandingan hasil belajar siklus 1 dan siklus 2

\begin{tabular}{|c|c|c|c|c|c|}
\hline SIKLUS & NTt & NTr & Mean & TK & Md \\
\hline & 100 & 50 & 75 & $73 \%$ & 80 \\
\hline $\mathrm{II}$ & 100 & 60 & 86 & $91 \%$ & 90 \\
\hline
\end{tabular}

$\begin{aligned} \text { Keterangan: NTt } & =\text { Nilai Tertinggi } \\ \text { NTr } & =\text { Nilai Terendah } \\ \text { Mean } & =\text { Rata }- \text { rata } \\ \text { TK } & =\text { Ketuntasan Kelas } \\ \text { Md } & =\text { Modus }\end{aligned}$

Hasil rekap sebagaimana tertera pada tabel 3 menunjukkan hasil penelitian dari siklus I ke siklus II banyak mengalami peningkatan. Peningkatan yang dimaksud terdapat pada aspek antara lain: (a) Nilai tertinggi pada semua siklus yakni 100, (b) Nilai terendah yang pada siklus I pada nilai 50, pada siklus II maningkat menjadi 60. Naik 10, (c) Rata - rata nilai pada siklus I sebesar 75, pada siklus II meningkat menjadi 86. Naik 11, (d) Ketuntasan pada siklus I sebesar $73 \%$, siklus II meningkat menjadi $91 \%$. Naik $18 \%$, (e) Modus tetap berada pada nilai 80 , pada siklus I dan pada siklus II menjadi 90. Dari data tersebut terlihat bahwa terjadi peningkatan hasil belajar dan peningkatan ketuntasan siswa terhadap nilai kriteria ketuntasan minimal siswa.

\section{KESIMPULAN}

Sesuai dengan data pada tabel 3, maka dapat disimpulkan bahwa prestasi belajar siswa mengalami peningkatan setelah diterapkan model pembelajaran talking stick pada Materi Sistem Administrasi Wilayah Indonesia pada siswa kelas VI semester I di SDN 3 Craken, Munjungan, Kabupaten Trenggalek.

\section{DAFTAR RUJUKAN}

Astuti, Pudji. 2006. IImu Pengetahuan Sosial. Bandung:Refika Aditama

Dinas Pendidikan dan Kebudayaan. 2002. IImu Pengetahuan Sosial. Jakarta:Depdiknas

Johnson David W and Roger T. Johnson. 2002. Cooperative Learning Methode: A Meta-Analysis. Journal of Research in Education. http://www.eeraonline.org/journal/files/2002/JRE_2002_01_DWJohnson. pdf

Kagan, S., \& Kagan, S. (1994). Cooperative learning (Vol. 2). San Juan Capistrano, CA: Kagan Cooperative Learning

Kauchak, D. P., \& Eggen, P. D. (1993). Learning and teaching. New York: Allyn Bacon, 2(3)

Lie, A. 2002. Cooperatif Learning. Jakarta: PT Grasindo

Moeliono, Anton.2001. Kamus Besar Bahasa Indonesia. Jakarta:Balai Pustaka

Pasaribu. 2001. Proses Belajar Mengajar. Bandung: Tarsito

Soemanto, Wasty. 2003. Belajar dan Pembelajaran. Yogyakarta: Teras

Suprijono, Agus. 2009. Cooperatif Learning Teori dan Aplikasi PAIKEM. Pustaka Pelajar: Yogyakarta

Suyatno, 2009. Menjelajah Pembelajaran Inovatif. Sidoarcjo: Masmedia Buana Pustaka

Widodo, Rachmad. 2009. "Model Pembelajaran Talking Stick". Tersedia pada http://wyw1d.wor dpress.com/2009/11/09/model-pem belajaran-16-talking-stik/ 